\title{
RUSSIAN-UKRAINIAN MILITARY CONFLICT IN AMERICAN, GERMAN AND UKRAINIAN POLITICAL CARTOONS: QUANTITATIVE AND QUALITATIVE ANALYSIS
}

\author{
Orest Semotiuk \\ Technical University Lviv \\ Mytropolyta Andreja str. 3, 79000, Lviv, Ukraine \\ e-mail: orest.semotiuk@gmail.com \\ https://orcid.org/0000-0002-7922-380X
}

The article is devoted to coverage of Russian-Ukrainian military conflict in American, German and Ukrainian political cartoons. Political cartoon is the subject of many different disciplines. From the linguistic point of view the political cartoon is a «creolized text». («multimodal text» or «hybrid text»). The perception of creolized text is a double decoding of information: at the visual level (symbols, visual metaphors) and at the verbal level (captions, phrases of cartoon's characters). This double-decoding provides the integral perception of the cartoon. Political cartoon combines different cultural codes to implement cognitive and communicative purposes, using a minimum of verbal and non-verbal means. The discursive modus of the conflict was analyzed by using of quantitative and qualitative methods (content analysis, frame analysis, metaphor analysis). This combination of methods provide objective and reliable research results.

Key words: political cartoon, creolized text, conflict, frame, content analysis, category, metaphor, script.

Introduction. Today, many applied and theoretical studies in linguistics are devoted to various problems of text and discourse. Text and discourse are rather complex phenomena and can be studied in various aspects: formal-structural, semantic, syntactic, pragmatic, functional, semiotic etc. For most of these studies the text is the source of the empirical material. Despite all the diversity of text sorts under study, political cartoon is of increasing interest to researchers.

Political cartoon is the subject of many different disciplines: cultural studies, communication and media studies, media linguistics, political science, political linguistics, cognitive linguistics, semiotics. This is due to the following reasons:

1) the political cartoon is a media phenomenon and at the same time an instrument for political communication and criticizing social shortcomings. It is perceived by a mass audience, has an impact on it and shapes its identity, reflects the «agenda» of a particular society;

(C) Семотюк O., 2019 
2) the political cartoon is a social and cultural phenomenon and provides precise temporal and local orientation;

3 ) the political cartoon is a special sort of text. It combines the verbal and nonverbal components. However, the political cartoon as a special sort of text is not a simple sum of these components, it is rather a completely new text and can be regarded as a result of their interaction. This sort of text is described by different researches as creolized, or multimodal, or hybrid text. (Grishaeva 2013, Voroshylova 2013, Sorokin 1990, El Refaie 2009, Ch. Achtenberg 1998, Th. Knieper 2013).

Political cartoon combines different cultural codes to implement cognitive and communicative purposes, using a minimum of verbal and non-verbal means. In this study we use the term «creolized text» and understand it as a synonym to «multimodal text» and «hybrid text». Creolized texts are texts, consisting of two non-homogeneous elements: verbal (lingual) and nonverbal (visual), which is a part of other sign systems than the natural language. The perception of creolized text is a double decoding of information: at the visual level (symbols, visual metaphors) and at the verbal level (captions, phrases of cartoon's characters). This double-decoding provides the integral perception of the cartoon.

But the political cartoon can be studied not only in the mentioned regards (text, media phenomenon, instrument of political communication). The political cartoon also enables and impacts the establishing and expressing of the image of politicians, political parties, and countries. Image is a stereotypical image of a particular object that exists in the mass consciousness. According to K. Boulding, «...image must be thought of as the total cognitive, affective and evaluative structure of the behavior unit or its internal view of itself and its universe» ${ }^{1}$. In parallel with the term image, and sometimes synonymously with it, the term stereotype are used, although image is, we believe, a more neutral and changeful notion than stereotype that has rather negative connotations and is more stable. Despite this difference, both terms have the common feature: they were formed under the influence of the primary or secondary experience of communicating with «others». When there is no primary (= own) experience, then secondary (=mediated) experience begin to «work» This experience include also the consumption of media content which shapes the image of the people or the country.

Purpose, corpus and methodology of the study. The purpose of this paper is to define and to describe the quantitative and qualitative characteristics of verbal and non-verbal tools used in political cartoons and the impact of these tools on public opinion and the image of political actors. Corpus includes 489 political cartoons from USA, Germany and Ukraine, dedicated to the Ukrainian-Russian military conflict. These cartoons were taken from the several web galleries:

www.radiosvoboda.org/media/photogallery

www.paolo-calleri.de

www.stuttmann-karikaturen.de

www.de.toonpool.com,

www.politicalcartoons.com.

www.cagle.com

\footnotetext{
${ }^{1}$ Boulding K. National Images and International systems. In: J.N. Rosenau (Ed.) International Politics and Foreign Policy. - New York. Free Press,1969. - p.422.
} 
The time frame of the study covers March 2014 - February 2016. Annexation of the Crimea, shooting down of the MH 17, G 20 summit in Brisbane, visit of A. Merkel and F. Hollande in Ukraine, G7 summit in Germany, Minsk II, four-foursome summit in Paris etc. define the social context of the study.

Before moving on to the description of the methodology we would like to make some theoretical remarks. After the beginning of Russian aggression in Ukraine we observe the instant growing of papers and books, considering such topics as «war», «conflict», «media and conflict», «hybrid war» in general and the Ukrainian-Russian military conflict in particular. Modern warfare is interpreted by experts as a kind of more complex concept of «military conflict». This last concept has two components: organized armed contingents and combat actions of a given intensity ${ }^{2}$.

This definition regards the war as a «material», «physical» phenomenon. At the same time, this «physical» modus/dimension of war coexists with its discursive modus/dimension: «an armed clash of any kind begins to exist as a war - thats means, as a historical and social

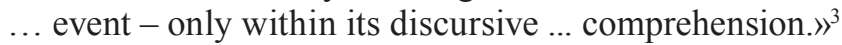

There is an asymmetry between these two modi/dimensions. In the «physical» modus/ dimension, the Russian-Ukrainian military conflict is locally limited (Crimea and Donbas). Instead, the discursive dimension of this conflict is exists at three levels: global, interstate (Russian-Ukrainian) and local (Ukrainian). Moreover, the interpretation of events at these three levels is different, and often even controversial. This conflict of interpretations, «is used during the hybrid warfare as a kind of weapon along with other non-military components of hybrid action» ${ }^{4}$.

Our study is methodologically based on: 1) the functional approach for relations between the media and politics, which considers shaping of the public opinion as one of the important tasks of the media; 2) the framing approach as part of the qualitative research. Main features of qualitative research are: understanding as the principle of cognition, case studies as the starting point for the analysis of ways of constructing social reality, texts are the as empirical material for the research. This approach is used to explore the principles of selection, organization and presentation of information and of accentuation in the media coverage; 3) The synergistic approach that enables the combination of quantitative and qualitative (semantic-cognitive) research techniques to study the relations between of «physical» and discursive modi of the Ukrainian-Russian military conflict. This multidimensional approach helps to obtain reliable and objective results with further quantification. In our study we used content analysis, semiotic analysis and framing analysis.

At the first stage, we conducted a content analysis of cartoons. This method is based on a system of codes (categories), developed by the researcher and their subsequent quantitative analysis. There are formal and content-related categories of content analysis. The formal ones include additional information on the research material (name, release date, material placement, heading). Content-related categories answer the questions What?

${ }^{2}$ Final Report on the Meaning of Armed Conflict in International Law. The Hague Conference (2010). Use of Force. Retrieved from: http://www.rulac.org/assets/downloads/ILA_report_armed_conflict_2010.pdf. ${ }^{3}$ Javorska G. M. Hybrid War as a Discursive Construct // Strategic Priorities. No. 4 (41), 2016. p. 42.

${ }^{4}$ Ibid., p. 45. 
Who? Where? When? and help to classify and systematize the research material. Categories are then divided into subcategories.

We developed the following formal codes: cartoon's type, cartoon with text, cartoon without text. Subcategories are: personal individual cartoon, personal group cartoon, impersonal cartoon, hybrid cartoon.

Personal individual cartoon (I) presents individual features of a well-known person in a hyperbolized form. Its gestures and facial expressions are corresponding to a situation or problem covered by a cartoon (Fig.1) A personal group cartoon (II) depicts a typical representative of a social group, political party or an entire nation, which stand for them (Fig.2). This type often uses personalization, national symbols (colors) of countries, or animal images. The impersonal cartoon (III) has no image of the person, and the problem criticized by the cartoonist is depicted through objects or symbols. These objects or symbols are connected by the viewer to the concrete events or persons. (Fig.3). After preliminary analysis of the our corpus, we decided to add another cartoon's type: hybrid cartoon (IV). In this cartoon the features described above are presented in various combinations: the image of politicians + national symbols, national symbols + animal images, typical representatives of the nation/ countries + national symbols etc.
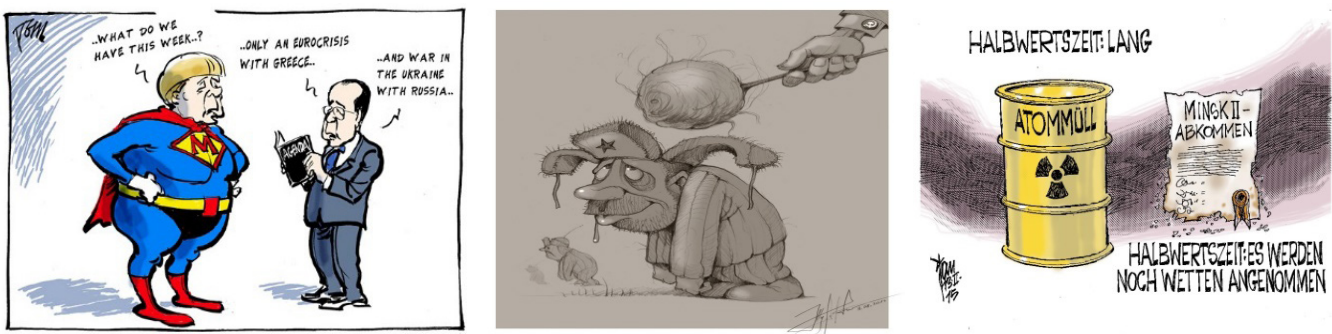

Fig.1 Personal individual cartoon. Fig.2 Personal group cartoon. Fig.3 Impersonal cartoon.

The content-related codes are: conflict participants (with the subcodes persons, countries, institutions, the ДНР, the ЛНР ${ }^{5}$ ), course of the conflict (with the subcodes annexation of the Crimea, Russian «humanitarian» convoy, crash of the MH 17, the delivery of American weapons to Ukraine, G20 / G7 summits, A Merkel's and F. Hollande's visit to Ukraine, the Minsk agreements), context of the conflict (with the subcodes revival of the Cold War, Russian aggression in the Caucasus), consequences (with subcodes sanctions, impoverishment of the population, losses for the world economy)

After the establishing of the system of categories, their quantitative analysis was carried out. We analyzed the number of cartoons and the distribution of cartoons with and without text (caption) in each content-related category (tablel in chapter Research findings). We also analyzed distribution of different cartoon's types in each content-related category and subcategories (table 2 in chapter Research findings).

The next stage of the study was the analysis of verbal and non-verbal means used in political cartoon to enhance its ironic or sarcastic effect. This feature is one of the most

\footnotetext{
${ }^{5}$ The Donetsk People's Republic and The Luhansk People's Republic are landlocked proto-states in eastern Ukraine, ocuppied by Russia.
} 
important in the political cartoon. Thus, following techniques enhance the ironic or sarcastic effect of the political cartoon: a) the caption or replica of characters contrast sharply with the situation depicted in the cartoons; b) allusions with films, computer games, characters of fairy tales, historical events and characters, c) wordplay, d) homophony. Some results of the analysis are presented in chapter Research findings, table 3.

At the next stage of the study, we applied a frame analysis to determine by what frames the Ukrainian-Russian military conflict is represented in political cartoons. Recently, the concept of «frame» is increasingly used in not only in linguistics, but also in other disciplines like media studies and political science. «To frame is to select some aspects of a perceived reality and make them more salient in a communicating context, in such a way as to promote a particular problem definition, causal interpretation, moral evaluation, and/ or treatment recommendation for the item described» ${ }^{6}$.

Framing is a process of reality construction between the producer and recipient of media content. This media content includes verbal texts (news) and nonverbal/visual texts (pictures and cartoons). In political cartoons frames can refer to overall motif, but also to particular key features of the cartoon. Frames are visual observations of situations/matters, events, persons.

There are two approaches to the analysis of frames in creolized texts in general and in political cartoons in particular: deductive and inductive. The first one involves the preliminary definition of frames without without prior acquaintance with the research material. The second one involves this acquaintance and preliminary analysis of the corpus, definition of the frames and their content based on the preliminary analysis of the corpus. In our study we combined both approaches, since using only an inductive approach may ignore frames that have been identified a priori. So, having preliminary analyzed the corpus, we defined 5 frames: aggression, responsibility, economic consequences, game, struggle. To identify this or that frame, we developed a set of 12 questions that should be answered with «yes» or «no». The answer «yes» to these questions means that particular frame is present in the cartoon, the answer «no» means «the frame is absent. 1. Aggression. This frame describes destructive behavior / attitudes, hostile actions, or military attacks in order to demonstrate the power or threat to apply it. To identify this frame, we asked: a) does the cartoon depict destructive behavior?; b) does the cartoon depict a military attack in the cartoon?; c) does the cartoon represent a demonstration of force or a threat to apply it?

2.Responsibility. This frame represents the problem, assuming responsibility for it or its resolution to a country or a politician. To identify this frame, we asked: a) does the cartoon «consider» that the character is responsible for the problem?; b) does the cartoon «consider» that the character can / must solve the problem?; c) does the cartoon «believe» that the problem needs an urgent solution?

3. Economic consequences. This frame describes the problem, or more exactly the consequences it will have for the institution or country. To identify this frame, we asked: a) does the cartoon depict financial or material losses?; b) does the cartoon indicate the economic consequences that will take place or will not take place after the actions depicted in the cartoon?

${ }^{6}$ Entman, Robert. Framing: Toward Clarification of a Fractured Paradigm // Journal of Communication 43(4), 1993, Autumn, p.52. 
4. Game. This frame describes the physical or mental competitions that the participants conduct according to the rules, being in front of each other. To identify this frame, we asked: a) does the cartoon show physical or mental competitions ?; b) does the cartoon contain images of people located in front of each other?

5. Struggle. This frame describes an event as a volitional effort aimed at defeating an opponent or achieving goals or preventing certain actions. To identify this frame, we asked: a) does the cartoon show an effort to defeat an opponent? b) does the cartoon contain images of people who are trying to achieve certain goals or prevent any actions?

The results and examples of frame analysis are in the Table 4.

At the final stage, we analyzed visual metaphors and and metaphorical scenarios/ scipts in political cartoons. We distinguish stereotyped, metaphorical and mixed/hybrid scipts. In the first case, the cartoon characters (e.g. politicians, statesmen) are depicted in their usual environment: conferences, negotiations, summits. Metaphorical scenarios «place» characters in the spheres, borrowed from real (medicine, circus, hunting) or fictitious (movies, tales, myths) world. These places originally are not typical for these characters. This enhances the humorous or satirical effect of the political cartoon. Mixed (hybrid) scenarios involve a mix of elements from different scenarios (for example, death is a party to peace negotiations).

Research findings. In this chapter we would like to present some of our findings and also to comment them. First we show the results of content analysis (table 1 and table 2).

\begin{tabular}{l|c|c|c|c|c}
\hline Category & Participants & Course & Context & Consequences & Total \\
\hline Total & 197 & 222 & 14 & 56 & 489 \\
\hline caption & 144 & 191 & 14 & 56 & 405 \\
\hline no caption & 53 & 31 & - & - & 84 \\
\hline
\end{tabular}

Table 1. Cartoons with and without text (caption) in each content-related category

\begin{tabular}{l|c|c|c|c|c}
\hline $\begin{array}{l}\text { Content-related category/ } \\
\text { Type of the cartoon }\end{array}$ & I & II & III & IV & Total \\
\hline Participants & 105 & 27 & - & 65 & 197 \\
\hline Course & 134 & 4 & - & 84 & 222 \\
\hline Context & 2 & 6 & 2 & 4 & 14 \\
\hline Consequences & 8 & 14 & - & 34 & 56 \\
\hline
\end{tabular}

Table 2. Different cartoon's types in each content-related category

As we can see, in our corpus (489 political cartoons) cartoons with the text prevail (405). The rest are cartoons without text (84). In this regard the actual cartoon's caption and also phrases or replicas of characters depicted in the caricature are interpreted here as «text». Most of the cartoons from our corpus refer to the categories conflict participants (197) and conflict course (222).

As to the distribution of different cartoon's types in the content-related categories, so we can see that most freuquent cartoon's type in content-related categories is personal individual cartoon, since modern politics is highly personified. This explains is a rather small amount percentage of impersonal cartoons in our corpus. The second most frequent 


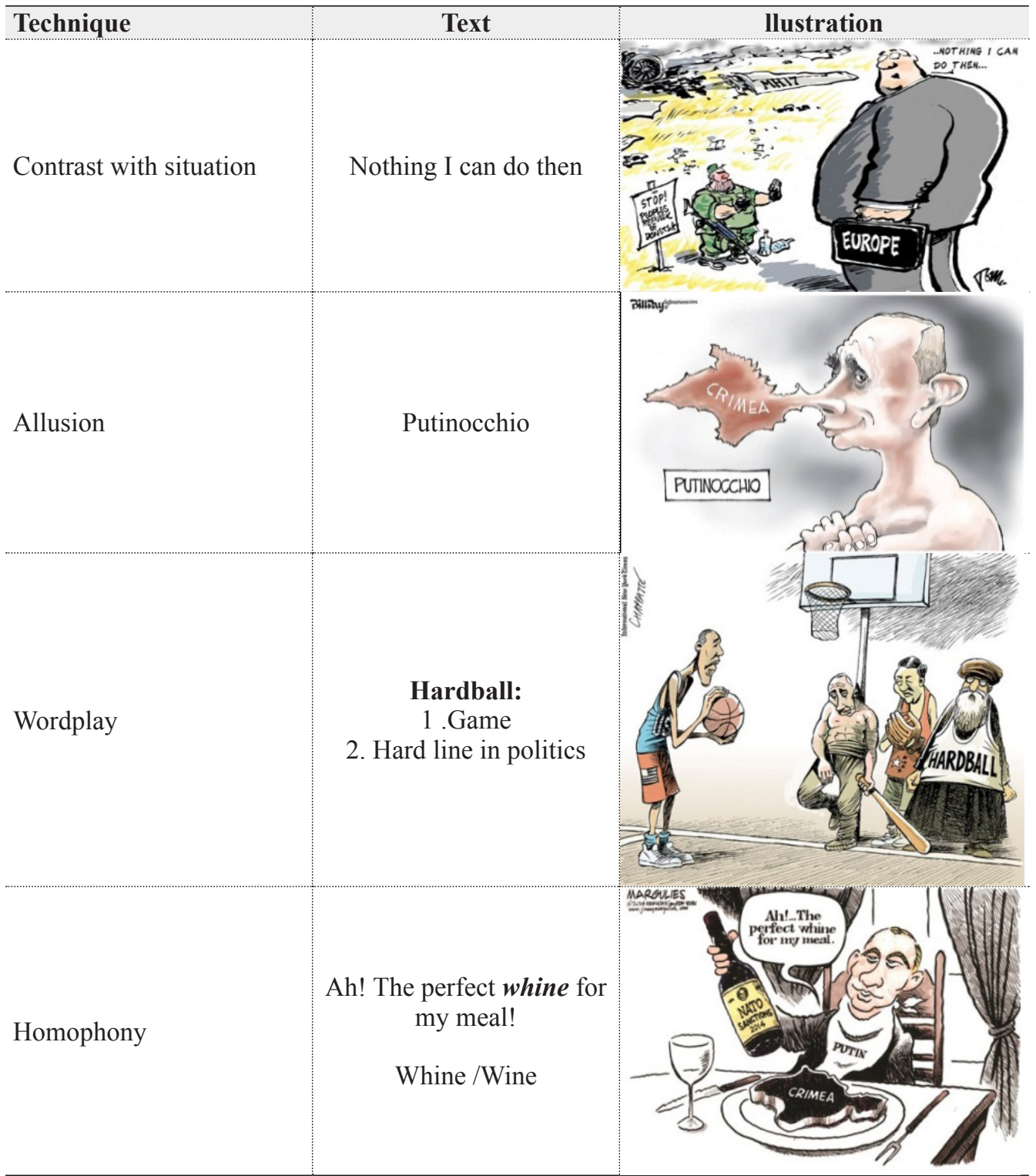

Table 3. Techniques providing the ironic/sarcastic effect in the cartoon

cartoon's type is a hybrid cartoon type, since the cartoon is a multidimensional phenomenon and his functionality is provided by various verbal and visual means: text, symbols, metaphors, colors etc.

Second we would like to present a sample of most important techniques in political cartoons which enhance the ironic or sarcastic effect. Considering the scope of the journal article we limit our examples to one or two cartoons for each stage of the analysis. On 
the first picture we see a huge figure of the OSCE officer and a small separatist who does not let an observer to step into the terrain of MH17 crash. The second cartoon refers to Pinnochio, a fabulous character whose nose grew up when he was lying. So did Putin after annexation of Crimea. The third cartoon we see US President Obama, Russian President Putin, and Presidents of China and Iran. US President is going to play basketball, but as we can see, other President are ready for hardball. This word means in English 1. Baseball. 2. Hard line in politics. The last cartoon shows Putin at the dinner table. Putin has a wine bottle with a label «NATO Sanctions 2014» in his hand. Putin says: «Ah! The perfect whine for my meal!». Here the technique of homophony is used: whine - a long, high-pitched complaining cry and wine (alcoholic drink). This mean, NATO sanctions after annexation of Crimea were harmless for Russia.

In the next table we show some examples for frames occuring in our corpus and their frequency.

\begin{tabular}{|c|c|c|c|c|c|}
\hline Frame & Aggression & Responsibility & $\begin{array}{c}\text { Economic } \\
\text { consequences }\end{array}$ & Game & Struggle \\
\hline $\begin{array}{l}\text { llust- } \\
\text { ation }\end{array}$ & & & 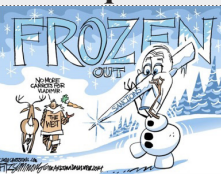 & & \\
\hline Number & 134 & 255 & 40 & 32 & 28 \\
\hline
\end{tabular}

Table 4. Frames in the cartoons and their frequency

The most frequent frames in our corpus are «responsibility» (255 cartoons) and «aggression» (134 cartoons). Less frequent, but also important are frames «Economic consequences», «Game», «Struggle». But we would like to mention, that one and the same cartoon may contain more than one frame, for example, «aggression» and «responsibility». This is the most common combination. The «game» frame has different implementations in political cartoons. The conflict is depicted as card game, puzzle game, chess game, restling, arm restling, squash. The frame «struggle» has different connotations in German and American political cartoons. German cartoonists frame the Ukrainian-Russian conflict as geopolitical confrontation between the USA and Russia. US-cartoonists see European Union and United States as partners in a joint struggle for Ukraine against Russia.

And finally we would like to present the results of the semiotic analysis (metaphors and scripts). We developed a scheme which enabled a complex analysis of methaphors and scripts in political cartoons (see table 5).

Regarding scripts in political cartoons the most freuqent of stereotypical ones are: NEGOTIATIONS, SUMMIT, CONFERENCE. Metaphorical scripts cover a wide range of sources: SPORT, CIRCUS, RESTASURANT/KITCHEN, RELIGION, MYTHOLOGY, TALE, THEATER, HOUSEHOLD, WAY, SHOP/SHOPPING, HOSPITAL/MEDICINE.

As for participants of the Ukrainian-Russian military conflict and their metaphorical representation in cartoons, we also note a wide range of metaphors. Considering the format of a journal article we simply provide here the list of the most frequent metaphors used for Ukraine, Putin, the ДНР and the ЛНР without deeper analysis of them. 


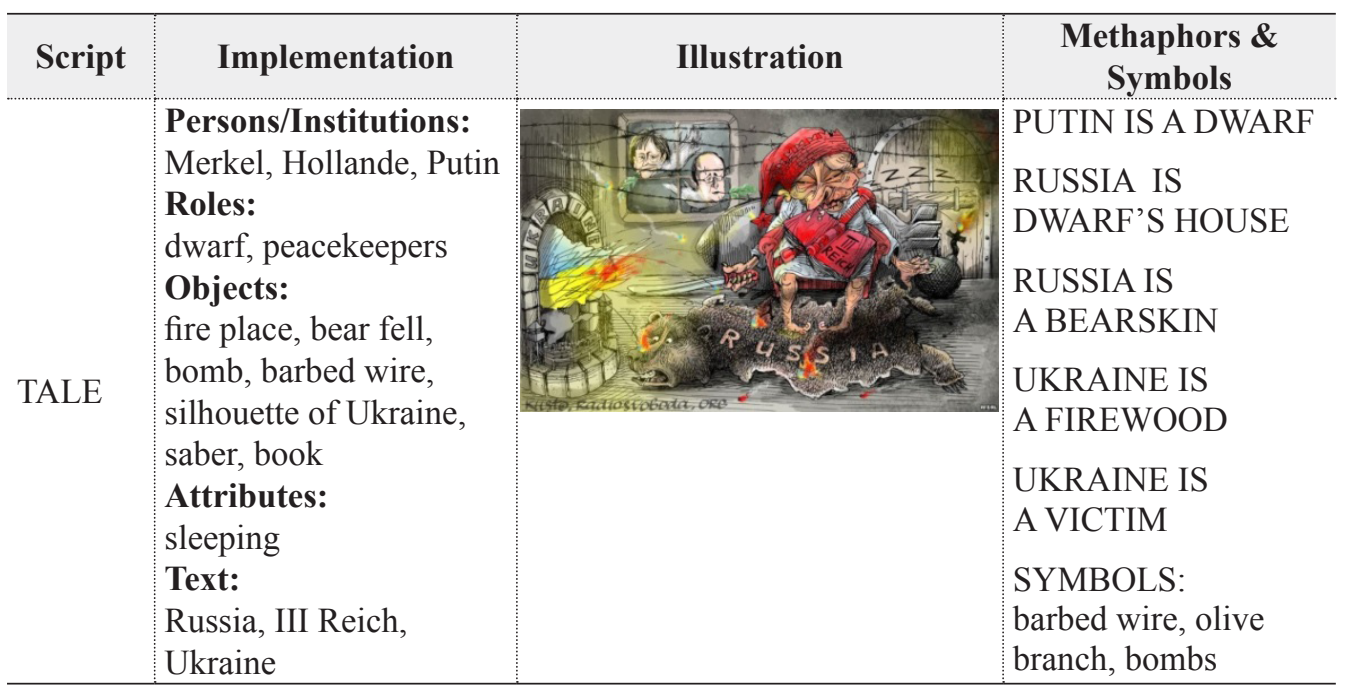

Table 5. Results of the semiotic analysis (metaphors and scripts)

Ukraine in political cartoons is represented by metaphors GIRL/WOMAN, HOUSE, FOOD; CHESSBOARD, FISH, EASTER EGG. The proto-states ДHР and ЛНP are depicted as JAIL, COFFIN, TRASH BIN. We should mention that these quasi-state formations occur only in Ukrainian political cartoons. Separatists in political cartoons are depicted mostly in connection with Putin as his DOGS, DOLLS, PUPPETS, VASSALS.

Considering metaphorical representation of Putin in political cartoons we can note, that this character is the most depicted one. The range of metaphors here is huge and only with negative connotations. Here the short list of metaphors: BANDIT, TERRORIST, MAFIOSO, THIEF, DWARF, WIREPULLER, VAMPIRE, PSYCHO, BLACKMAILER, BARBARIAN, DRUNKARD.

Conclusion. It should be emphasized that the discursive dimension of the UkrainianRussian military conflict is implemented at the global, interstate and local levels. This discurisve dimension of the conflict was analyzed on the corpus of 489 political cartoons from US, Germany and Ukraine using quantitative and qualitative methods. At the first stage we conducted a content analysis of cartoons with following formal and content based categories: cartoon's type, cartoon with text, cartoon without text; conflict participants, course of the conflict, context of the conflict, consequences. On the next stages we analyzed verbal and non-verbal means to enhance ironic or sarcastic effect of the political cartoon and frames that represent the Ukrainian-Russian military conflict in political cartoons. The most frequent techniques are contrast with the situation and allusion. As for frames, two most freuquently used frames in cartoons are responsibility and aggression or their combination.

On the final stage we analyzed the metaphorical representation of the UkrainianRussian military in political cartoons. We have discovered a wide range of metaphorical, stereotypical and blended scripts and visual metaphors.

Summing up, the combination of quantitative and qualitative methods enables objective and reliable research results. 


\section{REFERENCES}

1. Achtenberg Ch. Karikatur als Quelle. Determinanten sozialwissenschaftlicher Interpretation. Frankfurt a. M. u. a.: Peter Lang 1998 (Europäische Hochschulschriften: Reihe XXXI, Politikwissenschaft 372); 240 S.

2. Boulding K. National Images and International systems. In: J. N. Rosenau (Ed.) International Politics and Foreign Policy. New York. Free Press, 1969. P. 422.

3. El Refaie 2009 Multiliteracies: How Readers interptret political cartons. Visual Communication, 8(2), 75.

4. Final Report on the Meaning of Armed Conflict in International Law. The Hague Conference (2010). Use of Force. Retrieved from: http://www.rulac.org/assets/ downloads/ILA_report_armed_conflict_2010.pdf

5. Grishaeva L.I. The potential of caricature as an object of humanitarian research // Language, communication and social environment. Issue 11. Voronezh, 2013. P. 61-79.

6. Javorska G. M. Hybrid War as a Discursive Construct // Strategic Priorities. No. 4 (41), 2016. p. 42

7. Knieper Th. Die politische Karikatur: eine journalistische Darstellungsform und deren Produzenten H. von Halem, 2002. 346 S.

8. Sorokin Yu.A. Creolized texts and their communicative function // Optimization of speech influence. Moscow: Nauka, 1990. 240 p.

9. Voroshilova, M. B. Political Creolized Text: Keys to read: ; Ural. State pedagogical Institute - Yekaterinburg, 2013. 194 p. 


\title{
РОСІЙСЬКО-УКРАЇНСЬКА ВІЙНА У ПОЛІТИЧНИХ КАРИКАТУРАХ США, ФРН І УКРАЇНИ: ЯКІСНИЙ І КІЛЬКІСНИЙ АНАЛІЗ
}

\author{
Орест Семотюк \\ Національний університет «Львівська політехніка» \\ вул. Митрополита Андрея, 3, 79000, Львів, Україна \\ e-mail: orest.semotiuk@gmail.com \\ https://orcid.org/0000-0002-7922-380X
}

Стаття присвячена висвітленню російсько-української війни в американських, німецьких та українських політичних карикатурах. Матеріал дослідження складають 489 політичних карикатур, опублікованих на веб-галереях США, ФРН та України: www. radiosvoboda.org/media/photogallery; www.paolo-calleri.de; www.stuttmann-karikaturen.de; www.politicalcartoons.com. www.cagle.com. Часові рамки дослідження охоплюють березень 2014 - лютий 2016 рр.

Соціальний контекст дослідження сформували такі події: анексія Криму, аварія літака МН117, саміт Великої двадцятки в Брісбені, візити А. Меркель та Ф. Олланда в Україну, саміт G7 у Німеччині, Мінські переговори та ін. Політична карикатура є об'єктом дослідження різних наук: політології, культурології, прикладної лінгвістики (політичної лінгвістики і медіалінгвістики), семіотики, когнітивної лінгвістики, медіапедагогіки. Це пояснюється такими причинами: 1) карикатура є поліаспектним медіафеноменом і водночас засобом політичної комунікації та критики соціальних недоліків; вони впливають на формування картини світу та відображають порядок денний суспільства; 2) карикатура $є$ соціально-культурним феноменом, який має точну локальну і часову прив'язку. 3) політична карикатура $є$ ефективним засобом формування іміджу країни, народу чи окремого політика. 3 погляду медіалінгвістики політична карикатура є креолізованим (гібридним, мультимодальним) текстом.

Автори політичної карикатури поєднують різні культурні коди для реалізації когнітивних і комунікативних цілей, використовуючи мінімум вербальних та невербальних засобів. Розкодування такого тексту відбувається на двох рівнях: візуальному/невербальному (символи, візуальні метафори, метафоричні сценарії, візуальні фрейми) і на вербальному (підписи, заголовки, вставки, фрази персонажів). Таке подвійне розкодування забезпечує цілісне сприйняття політичної карикатури і посилює їі комунікативний ефект. Дискурсивний вимір українсько-російського військового конфлікту було проаналізовано з допомогою кількісних та якісних методів (контент-аналіз, фреймовий аналіз, мультимодальний дискурс-аналіз). Таке поєднання методів забезпечило об'єктивні та надійні результати.

Ключові слова: політична карикатура, креолізований текст, конфлікт, фрейм, контент-аналіз, категорія, метафора, сценарій. 